\title{
Challenges in Teaching and Learning of English at Secondary Level Class X
}

\author{
Roshan Ali Teevno \\ PHD Scholar, Iqra University Karachi, Pakistan \\ E.mail: teevno@yahoo.com
}

Received: September 14, 2011 Accepted: October 9, $2011 \quad$ Published: October 21, 2011

Doi:10.5296/ijhrs.v1i2.1029 URL: http://dx.doi.org/10.5296/ ijhrs.v1i2.1029

\begin{abstract}
This paper describes the challenges faced by teachers and students in teaching and learning of English at secondary level. The study was limited to class x. It has been observed that in recent times the governments of Sindh and Pakistan have been providing a lot of facilities including free books and training programs for the teachers at secondary level but the teaching and learning of English is not up to mark. The participants of the study were 11 English teachers including 7 male and 4 female, 70 students including 40 male and 30 female and also; 6 English experts which include 4 male and 2 female. Teachers and students were administered questionnaires and involved in focus group discussion and experts were interviewed. It was found that teachers had no proper training of teaching English, proper facilities were not provided and curriculum was not according to the needs of students. These reasons hindered the teaching and learning process of English. This study was carried out at one of the taluka of district Naushahro Feroze Sindh Pakistan.
\end{abstract}

Key words: English teacher, Learners, Challenges, Secondary level, Existing practices 


\section{Introduction}

After the 1950s there has been great advancement in communication as a result of which world has become global village. This gave birth to need of common language which was English. These days English is called language of economic system, international tourism, electronic information and higher education.

Over 80 percent international organizations in the field of international relations make official use of English (Mackay, 2002:17).

In Asia and the pacific some $90 \%$ of organizations use only English for their official proceedings (ibid). Nehru said, ' English is our major window of the world.'

"English is not a subject which can be taught; it is a subject which must be learnt." (Michel West). F. G French said, "No language ancient and modern can be compared with English in number of its speakers, writers and readers all over the world."

English language teaching is regarded as being far from satisfactory in the country, not conducive to learning the language (Warsi, 2004). Teaching and learning of English in Pakistan is based on the system of grammatical patterns and there is a trend of formal and bookish language, students just produce sentence and focus on reading and writing (Nunan, 1988, p 27).

Realizing the need of the English language many training programs to teach English has started. In this connection, Sindh government, in the collaboration with British council, Society of Pakistan English teacher (SPELT) and The Aga Khan University arranged English language teaching (ELT) programmes to provide professional assistance to teachers across the province.

It has been witnessed that, in recent times government has taken several measures to improve the quality of English language in the country. However, it has been felt that, there is not satisfactory progress in the improvement of English language.

In this connection this study was conducted in one of the districts of Sindh Pakistan to find out why English teaching and learning is not improving.

The aims of this study were to find out what problems teachers face in teaching English and what problems students face in learning English and also; what academic 
facilities have been provided for teaching and learning of English at secondary level. It was also one of the aims of the study to observe the existing practices of teaching English at secondary level.

This study helped out to suggest the government some important measures to improve the quality of teaching and learning of English at secondary level with special reference to one of the districts of Sindh Naushahro Feroze.

According to (Warsi, 2004) translation method is still being used in most of language programmes. Language teaching programmes are not according to the needs of teachers and learners (ibid). These views also tell us that in Pakistan, there are still traditional methods of teaching. We know that method is essential for any kind of development in any language especially for learning any second or foreign language. In this context the use of modern methods in Pakistan for learning English has been the dream because the teachers teaching English have no knowledge of modern methods.

After all above discussion we can conclude that generally in Pakistan there are too many hindrances in teaching and learning of English which include over crowded classes, use of traditional methods, faulty examination system, and non availability of require facilities etc.

In spite of all the efforts made by the public and private sector the good results are still awaiting and we still need to do a lot in order to have the desired results. It is difficult for the teachers who are not the native speakers to teach English. Especially in Sindh, the situation is not satisfactory, particularly in rural areas the situation is not as good as it should have been. Therefore, this study attempts to find out challenges faced by the teachers as well by the students studying at the secondary. This study will also help find out the actual practices of teaching in the class.

\section{Research questions}

Following were the research questions of this study.

- What method teachers use for teaching English?

- What problems do students face in the classroom in learning English?

- What academic facilities have been provided for teaching of English? 
- What needs to be done to resolve the existing challenges in teaching and learning process of English at secondary level?

\section{Methodology}

\section{Strategy of the study}

The study employed mix methodology. For quantitative part questionnaire was administered to teachers and students to find out the actual problems they face in teaching and learning of English. They were also asked about the facilities available to them for teaching learning process. Class rooms were also observed. For qualitative part focus group discussion one each for teachers and students was organized so that their opinions could be gathered about the topic. For the expert opinion on curriculum effectiveness or suitability four subject specialists of English were interviewed.

This study was carried out at one of the taluka of district Naushahro Feroze Sindh Pakistan.

In particular taluka there were fourteen public high schools (male and female). In these schools there were 1000 students and 19 English teachers. 07 schools, 11 teachers and 70 students were taken as sample while using stratified sampling giving due representation to male female and rural/urban schools.

\section{Plan for Data analysis}

Collected data was analyzed on computer as well as manually..

\section{Procedure of the study}

First of all, the required research tools were developed which include questionnaires for teachers and students, check list for classroom observation and schedule for interview with subject specialists of English. Through questionnaires teachers and students were asked about difficulties they faced in the process of teaching and learning of English. They were also asked about the facilities like provision of appropriate furniture, availability of computer labs, libraries, provision of English news papers, books, audio-visual aids like tv,tape recorder, charts, pictures, over-head projector, multi-media etc.

Through classroom check list existing practices of teaching and learning of English 
were observed. In focus group discussion more perceptions of teachers and students were sought about English teaching and learning. In interview with subject specialists it was tried to find out the opinions of these specialists about the effectiveness of English curriculum at secondary level.

Findings were extracted from the analyzed data and recommendations were made for different concerned people

To maintain the trustworthiness and authenticity of the data, the researcher completed every step of the study personally.

\section{Findings:}

After the analysis of the data, many challenges/issues/facts regarding teaching-learning of English have been identified. It was found that teachers were lacking in on job trainings and refresher courses especially, of English language teaching. In addition to this, teachers do not get training in syllabi change, mostly teachers use Grammar Translation Method, no awareness of Communicative Teaching Method, a few of teachers as well as students use English language in their classrooms, no development of reading, writing, speaking and listening skills, a few teachers use pair work and group work techniques. Though majority of the schools have their libraries but none of these have the provision of English newspapers, no computers, and audio visual aids. The classes were over crowded and English is being taught as a subject not as a language. Lesson planning, insufficient time allocation, classroom management, modification in curriculum of English, and improper inspection system were some other challenges in the development of English Language in the secondary schools were found. One positive point in whole picture was the teaching experience of the teachers in ELT; because most of the teachers had more than eleven years. But on the other hand most of the students do not ask questions, and their emphasis is on reading skill especially on aloud reading skill. 
Table: 1 Findings

\begin{tabular}{|c|c|c|}
\hline S. No & Area of interest & Results in \% \\
\hline 1. & Teachers' Training and Refresher Courses & $63.63 \%$ \\
\hline 2. & Training in Case of Curriculum Change & $0.0 \%$ \\
\hline 3. & Use of Grammar Translation Method & $90.90 \%$ \\
\hline 4. & Awareness and use of Communicative Method & $0.0 \%$ \\
\hline 5. & English as a Medium of Instruction & $30.00 \%$ \\
\hline 6. & Students use English as a medium of communication & $27.27 \%$ \\
\hline 7. & Use of Four skills of English Language & $0.0 \%$ \\
\hline 8. & Pair-work or Group work techniques & $27.27 \%$ \\
\hline 9. & Creativity among students by home work & $0.0 \%$ \\
\hline 10. & Libraries in schools & $50.00 \%$ \\
\hline 11. & Provision of English Newspapers & $0.0 \%$ \\
\hline 12. & Availability of Computers & $0.0 \%$ \\
\hline 13. & English as a subject & $100.00 \%$ \\
\hline 14. & English as a language & $0.0 \%$ \\
\hline 15. & Over-crowded Classes & $63.63 \%$ \\
\hline 16. & Use of A.V. aids & $0.0 \%$ \\
\hline 17. & Lesson Planning & $0.0 \%$ \\
\hline 18. & Insufficient time allocation & $54.54 \%$ \\
\hline 19. & Classroom Inspection System & $0.0 \%$ \\
\hline 20. & Modification in English Curriculum needed & $50 \%$ \\
\hline 21. & Classroom Management & $0.0 \%$ \\
\hline 22. & Teaching Experience in ELT & $72.72 \%$ \\
\hline 23. & Passage Translation into Mother tongue & $100.00 \%$ \\
\hline 24. & Use of reading skill & $100.00 \%$ \\
\hline 25. & Students ask questions & $36.36 \%$ \\
\hline
\end{tabular}




\section{Recommendations and discussions}

- Teachers should try to encourage students to use English as medium of communication not only in the class but also at home as well. Child centered activities are necessary to be used in the class.

- They should also try to learn and use modern methods of teaching including communicative method in the class room. Students should be given creative home work.

- Efforts should be made to promote all four skills (speaking, listening, reading and writing) of English language in the classroom. Teachers should also try to encourage students to read English news papers and same be provided to schools. Teachers should prepare lesson plans and should deliver them with the help of audio visual aids which could create realistic situation for teaching of English.

- Students are advised to use English language in the classroom as well as at home so that, they can get good practice. They should ask questions from the teachers in the classroom and get your concepts cleared. Students need to work properly and come to school regularly and emphasize to develop all four skills while learning English and promote self study.

- They should try to watch English programs when they get free time, specially listen to English speeches. If possible students should try to use internet for learning English.

- Curriculum should be reviewed after some specific time. All the stake holders, including students, teachers, parents and administrators should be included in the committee for reviewing the curriculum.

- Curriculum should be child centered and activity based which could promote English as language not as subject. Curriculum should be based on modern teaching methodologies. 
- Teachers should be trained keeping in view the changes made in the curriculum. More creative exercises based on four skills (speaking, listening, reading and writing) should be included in the text book of English.

- Parents should encourage their children to use English at home and class.they should also try to buy their children different English books and magazines especially English news papers and make sure that children read them on the regular basis.Parents should also make sure that their children attend their classes regularly. They should also have close contact with the teacher so that, they can inquire about the study and class performance of their children.

- The administrators should try to motivate teachers for attending the classes regularly and make use o English language in the class. They should try to provide required facilities in the schools. They should try to provide professional assistance to the teachers.

- Teachers to use audio-visual aids and modern methods of teaching during the teaching of English.

\section{Bibliography}

- Chughatai, N. 1990. An Investigation in to the Nature and Causes of Difficulties in Learning English by the Students at Secondary level. Ph. D. thesis, Institute of Education and Research, University of Punjab Lahore, Pakistan. PP. 295

- Crystal, D, (1997), English as global language. Cambridge: Cambridge University Press.

- Dr: Y.K Singh, Teaching of English, APH Publishing Corporation5, Ansari Road, Darya Ganj new Delhi

- Government of Pakistan. 1974. A Research Report on Development of English Curriculum Committee, National Bureau of Curriculum and Text books, Islamabad, Pakistan. p. 9.

- Mackay, S. L. (2002) Teaching English as an International Language. Oxford: Oxford University Press 
- Lionel, M. 1985. Students Choice: Short Reading for the ESL, Classroom English Teaching Forum DC. Vol No-1 Washington, USA. PP. 87-90.

- Mansoor, S. (2002) “Culture and teaching of English as second language for Pakistani students.'

- Mansoor, S. 1993. Punjabi, Urdu, English in Pakistan. Vanguard Book Pvt, Ltd, Lahore, Pakistan pp. 8, 159.

- Mirza, M. 1986. Evaluation of English Curriculum for Secondary Classes Research and Development Centre, Lahore, Pakistan. PP. 76-90.

- Ministry of Education (MoE). (2007) Press Release February 9, 2007. Islamabad: government of Pakistan . retrieved from http/ www.moe.gov.pk/ mediacell.htm

- Qureshi, S. M. 1965. A survey of the causes of failure in the secondary school certificate examination of the students of the government boys' high schools of peshawar disrtrict (Unpublished) M.Ed thesis, University of Punjab Lahore, Pakistan. p. 48.

- Saiful Haq, New approaches to teaching English, KITAB MAHAL, Urdu Bazar Lahore

- Shirani, M. R. 1995. Utility of Direct Method for the Development of Language Teaching (Unpublished) M.A, TEFL, thesis, AIOU, Islamabad, Pakistan. pp 26-48.

- University Grants Commission. (1992) Report on the teaching of languages. Islamabad: Government of Pakistan.

- Warsi, J. (2004), “conditions under which English is taught in Pakistan: An Applied Linguistic Perspective.” SARID Journal, 1 (1), 1-9, retrieved from http:// www.saridjournal.org/2004/warsi.htms 